\title{
What does changing the law change? Prostitution and the law in action: National regulation and local practices of public- health policy in Germany
}

ClaUdia VorheYER*

Vorheyer, C., 2018. What does changing the law change? Prostitution and the law in action: National regulation and local practices of public-health policy in Germany. Oñati Socio-legal Series [online], 8 (8), 1179-1196. Received: 14-07-2017; Accepted: 12-11-2018. Available from: https://doi.org/10.35295/osls.iisl/0000-0000-0000-0938

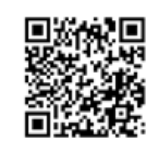

\begin{abstract}
This paper presents key findings from a qualitative-empirical research on prostitution governance that examined the professional habitus of governmental and nongovernmental frontline actors, such as police and public-order officers as well as social workers and employees of public-health services, in Germany. It has been carried out after fundamental changes within German prostitution policy. The paper focuses on the public-health sector to demonstrate exemplarily how and to what extent professionals' patterns of perception, thought and action have a crucial impact on the implementation of prostitution policy, up to the point that their everyday practices counteract the "law in books". To provide a better understanding of this, the empirically grounded and refined concept of professional habitus will be outlined and illustrated by a contrastive case comparison. Moreover, against the background of the current policy change reversal, the article takes up the concept of "morality politics" and relates it theoretically to the concept of "professional habitus".
\end{abstract}

\section{Key words}

Prostitution; governance; policy; Germany; law in action; street-level bureaucracy; public health; actor-centred institutionalism habitus; Bourdieu; morality politics

\section{Resumen}

Este artículo presenta hallazgos claves de una investigación cualitativa-empírica sobre la gobernanza de la prostitución que estudió el habitus profesional de actores principales gubernamentales y no gubernamentales, así como de trabajadores sociales y empleados de servicios de salud pública en Alemania. La investigación se realizó después de cambios fundamentales en la política sobre prostitución de Alemania. El artículo se centra en el sector de salud pública para demostrar

\footnotetext{
* Claudia Vorheyer PhD, is a sociologist at University of Zurich. Her research interests involve the governance of prostitution and trafficking for the purpose of sexual exploitation, whose bottom-up analysis proved to be highly relevant both disciplinary and interdisciplinary as well as for the realm of practice. Related publications include: Claudia Vorheyer (2017): Knowledge production on human trafficking and everyday governance practices, in: Ryszard Piotrowicz, Conny Rijken, Baerbel Heide Uhl (ed.): Routledge Handbook of Human Trafficking, pp. 395-406. Her current research projects focus on onward migrants' trajectories as well as the concept of "common good". Contact details: Institute of Sociology, University of Zurich, Andreasstrasse 15, 8050 Zurich, Switzerland. Email address: vorheyer@soziologie.uzh.ch; ORCID: https://orcid.org/0000-0001-6761-0637
}

\section{(cc) $\mathrm{EY}$-NC-ND}

Oñati International Institute for the Sociology of Law Antigua Universidad s/n - Apdo.28 20560 Oñati - Gipuzkoa - Spain

Tel. (+34) 943783064 
ejemplarmente cómo y hasta qué punto los modelos de percepción, pensamiento y acción de los profesionales tienen un impacto crucial en la implementación de políticas sobre prostitución, hasta el punto de que su práctica cotidiana contraviene la ley escrita. Para explicar mejor esto, se definirá e ilustrará el concepto empíricamente fundamentado y refinado de "habitus profesional".

\section{Palabras clave}

Prostitución; gobernanza; política; Alemania; derecho en acción; burocracia a nivel de calle; salud pública; habitus de institucionalismo centrado en el actor; Bourdieu; políticas de moralidad 


\section{Table of contents / Í ndice}

1. Introduction: Prostitution policy.

Past and present paradigm shifts in Germany 1182

2. Law in practice between structure and agency. Actor-centred institutionalism and Bourdieu's "habitus" concept.

3. Methodology: Making use of expert interviews to explore the law in practice 1186

4. Findings: Professional habitus and individualised governance practices...

4.1. Theoretical model: Professional habitus formations

concerning prostitution governance

4.2. Case comparison: Divergence of "policy in use":

Control-oriented vs. prevention-oriented public health approach............. 1188

5. Discussion: Prostitution governance and street-level bureaucracy:

Professional habitus in the context of morality politics

References.

Legal sources

1196 


\section{Introduction: Prostitution policy. Past and present paradigm shifts in Germany}

Prostitution policy in Europe and beyond is characterised by genuine diversity. To classify and compare national prostitution policies, researchers have applied various general categories, such as "prohibitionism", "(new) abolitionism" and "regulationism" (Di Nicola et al. 2005). Criticising those and other categories for various reasons, Östergren (2017) suggested a new typology to provide a clearer conceptual framework that turns on whether a national policy "represses", "restricts" or "integrates" sex work into the overall societal, legal and institutional framework. German prostitution policy is predominantly restrictive, as criminal as administrative law and local ordinances regulate under which conditions sex work is allowed to be exercised. However, significant paradigm shifts occurred over the last decades. Instead of discussing the "law in books" (de jure) in form of national legislation and policy, the present article focus on the "law in action" (de facto) - that is, the concrete governance practices at the implementation level. Drawing on qualitative interviews with frontline actors, we will explore their professional habitus formations in terms of their issue- and work-related patterns of perception, thought and action. Indeed, for the administrative staff existing policies on prostitution establish not only a relevant framework for orientation but also a legal obligation to implement them.

Remarkably, over the last 15 years, German legislation concerning prostitution in general and public health in particular underwent two fundamental changes (see Table 1). The first impulse for national reform came from the courts (Mattson 2016, 99). In a very prominent decision in 2001, the Berlin State Court ruled that prostitution could no longer be classified as an offence against common decency and good morals (Sittenwidrigkeit). In the wake of this decision, the Prostitution Act (in full: Law for the Regulation of the Legal Relations of Prostitutes) and the Infection Protection Act (Law on the Prevention and Control of Infectious Diseases in Humans) were enacted in 2001 and 2002, respectively. ${ }^{1}$ Both represent an increasing normalisation of prostitution, legally as well as socially. The Infection Protection Act revised the legal framework for public-health policy that had been in existence since 1953, particularly concerning sexually transmitted diseases (STDs). Its enactment abolished compulsory health examinations for persons who are considered a highrisk group on account of their engagement in prostitution and introduced provisions requiring an approach to public health oriented toward general prevention instead. Against the backdrop of this policy, the role of public-health authorities was no longer to control prostitution but to promote and support personal health-related behaviour by providing voluntary, anonymous and free-of-charge services. Moreover, the Prostitution Act was meant to improve the legal and social situation of sex workers by facilitating access to statutory social-insurance systems and thus to health care, unemployment insurance and pension schemes. The conjunction of the two laws outlined above has often been referred to as a paradigm shift in prostitution governance (Steffan et al. 2002, Galen 2004). By legally bolstering sex workers' labour status and generally recognising prostitution as an occupational activity, this legal arrangement tended, "de jure", towards an integrative approach, which understands sex work as a multifaceted social phenomenon containing negative elements rather than solely a negative one (Östergren 2017). Nonetheless, exactly 15 years thereafter, prostitution policy in Germany has undergone yet another drastic change. A comprehensive new law called Prostitutes Protection Act (Law for the Regulation of the Prostitution Industry and for the Protection of Prostitutes) came into force in July 2017 (see Table 1). ${ }^{2}$ Among its explicit aims are to enhance the

\footnotetext{
${ }^{1}$ The German title of the Infection Protection Act is "Infektionsschutzgesetz" (Gesetz zur Verhütung und Bekämpfung von Infektionskrankheiten beim Menschen), with the legal acronym "IfSG". The German title of the Prostitution Act is "Prostitutionsgesetz" (Gesetz zur Regelung der Rechtsverhältnisse der Prostituierten), the legal acronym being "ProstG".

2 The German title of the Prostitution Protection Act is "Gesetz zur Regulierung des Prostitutionsgewerbes sowie zum Schutz von in der Prostitution tätigen Personen" with the legal acronym "ProstSchG".
} 
protection of sex workers as well as increase transparency in the sex-work sector and regulate it uniformly. Even its opponents agree on these objectives, but they express serious concerns about the associated rules and obligations to which the prostitutes are now subject, above all, the obligation to register with local authorities as well as to undergo mandatory and regular health counselling services (as prior to the previous reform). Such surveillance and control, critics argue, jeopardises the success that the prevention-oriented public-health approach had achieved over the past decade. This newly enacted law reverses prostitution policy not only in terms of its public-health approach. Its general shift of focus is indicated by the modification of the title from Prostitution Act (2002) to Prostitutes Protection Act (2017). In contrast to the former legal shift, contributing to a normalisation process, the current policy model points to the opposite direction by mandating authorities with increased control over sex workers in order to "protect" them. Therefore its opponents characterise it as a "moralising law" growing out of an "infantilising" or "patronising feminism" (Frommel 2015). With this in mind, it can be concluded that prostitution policy in Germany has presently moved back towards a more restrictive model, which even seems to include some elements of a repressive approach regarding the understanding of sex work, the stated policy intention and its underlying ideology.

TABLE 1

\begin{tabular}{|c|c|}
\hline $\begin{array}{l}\text { Legal framework } \\
\text { explicitly addressing prostitution }\end{array}$ & $\begin{array}{l}\text { Legal framework } \\
\text { addressing public health }\end{array}$ \\
\hline $\begin{array}{l}\text { Before 2002: } \\
\text { No law (beyond the criminal code) } \\
\text { explicitly addressing prostitution. }\end{array}$ & $\begin{array}{l}\text { 1953: } \\
\text { Law on combating sexually transmitted } \\
\text { diseases (GeschlKRG) (in FRD). }\end{array}$ \\
\hline \multicolumn{2}{|c|}{ Paradigm shift: Change towards an “integrating” policy model } \\
\hline $\begin{array}{l}\text { 2002: } \\
\text { Prostitution Act (ProstG) } \\
\text { Law for the Regulation of the Legal Relations } \\
\text { of Prostitutes. }\end{array}$ & $\begin{array}{l}\text { 2001: } \\
\text { Infection Protection Act (IfSG) } \\
\text { Law on the Prevention and Control of } \\
\text { Infectious Diseases in Humans. }\end{array}$ \\
\hline \multicolumn{2}{|c|}{ Paradigm shift: Change (reversal) towards a more "restrictive” policy model } \\
\hline $\begin{array}{l}\text { 2017: } \\
\text { Prostitutes Protection Act (ProstSchG) } \\
\text { Law for the Regulation of the Prostitution } \\
\text { Industry and for the Protection of Prostitutes. }\end{array}$ & $\begin{array}{l}\text { 2017: } \\
\text { Prostitutes Protection Act (ProstSchG), } \\
\text { particularly Part } 2 \text { (“Prostitutes”), } \\
\S 10 \text { (“Health Counselling”). }\end{array}$ \\
\hline
\end{tabular}

Table 1. Present changes in the legal framework and prostitution policy in Germany.

These previously reconstructed paradigm shifts raise at least two central questions: first, how or why did they occur, and second, what does changing the law change. As for the first issue, to explain such a reversal of policy reform - in this case of public health, from compulsory registration and mandatory health examinations for prostitutes (Law on Venereal Diseases, 1974) towards prevention services (Prostitution Act, 2001) and then back to compulsory registration and mandatory (health) counselling (Prostitutes Protection Act, 2017) - Wagenaar and Altink's (2012) conceptualisation of prostitution policy as an instance of "morality politics" is enlightening. One of its defining characteristics is that morality politics is vulnerable to abrupt and drastic changes as it draws on utterly different values and underlying principles (Wagenaar and Altink 2012, 284). As the authors state, "the 
noncompromising nature of morality politics results in a situation in which policy debate is never settled". Thus, they conclude, "that is what makes it politics instead of policy" (Wagenaar and Altink 2012, 285). In order to answer the second question of what changing the law changes in terms of governance practices, we need to look closely at the law in practice, the mundane details of policy implementation, as Wagenaar and Altink (2012) emphasise. This precisely is what the qualitative empirical study presented here does.

Following this introduction, I would like to outline a theoretical perspective of governance practices by drawing on the approach of actor-centred Institutionalism (Mayntz and Scharpf 1995) as well as Bourdieu's (1990) conception of "habitus". I will then describe the research methodology, which relies on theory-generating expert interviews. In the main part of the article, I will present the key research findings, which include an empirically grounded and refined concept of professional habitus. This is illustrated by a contrastive case comparison that also demonstrates the variation in governance practices at the implementation level. The article concludes by discussing the emerging concept of "individualised governance practice" in the context of "street-level bureaucracy" (Lipsky 1980) and "morality politics" (Wagenaar and Altink 2012).

\section{Law in practice between structure and agency. Actor-centred institutionalism and Bourdieu's "habitus" concept}

The integrative approach of actor-centred institutionalism (Mayntz and Scharpf 1995), which was not only designed for but also developed in the context of governance studies, provides the theoretical framework for this research (article). Its key assumption is the dual constitution of institutions and organisations through structure and agency based on the interplay between organisational structures and practices of the agents operating through them. From this perspective, an organisational setting is (re-)produced, or changed, by the actions of its individual members, while their choices and opportunities are at the same time influenced and constrained by the organisational context. Accordingly, an analysis of organisational structures without reference to social actors is as incomplete as an analysis of those actors' behaviour without reference to organisational structures, as Jackson (2009, $8 \mathrm{ff}$.) pointedly describes the basic assumption of actor-centred institutionalism.

With respect to the law in action, the approach raises awareness that while organisational structures as well as legal frameworks, policies and regulations do indeed shape social actors' roles, aims and identities, they never fully determine them. As organisational practice systematically involves scope for interpretation and action, organisational staff is able to modify, transform or even neglect them based on their individual or collective orientations (Mayntz 1997). As any other member of society, frontline governance actors belong to a variety of social groups and categories besides their organisational and professional affiliation, for instance, to a certain social class or milieu, generation, gender or even religion, which may affect their cognitive and motivational focus and work performance, as Mayntz (1997) stresses. Moreover, in areas of "morality politics" such as prostitution, it is likely that societal discourses and media consumption play a particularly important role as well (Wagenaar and Altink 2012).

To explore everyday governance practices and examine their underlying logic, Bourdieu's (1990) influential concept of "habitus" provides an appropriate and suitable theoretical frame of reference. In line with actor-centred institutionalism, Bourdieu's theoretical approach deals with the dialectic relation of social structure and agency. It represents a system of embodied dispositions that organise the ways in which individuals perceive and react to the social world around them. More precisely, the habitus consists of patterns of perception, thought and action. The schemes of thought can be further distinguished into, first, schemes of cognitive order such as everyday theories and classification patterns, second, implicit ethical 
norms for evaluating societal acts and, third, aesthetic standards for evaluating cultural objects and practices. According to Bourdieu (1990), such dispositions are socially caused, meaning that they are acquired through individual and collective biographical experiences and in processes of socialisation.

Theoretically speaking, the habitus concept aims to explain social and group-specific practices. However, the specific focus of analysis defines which aspects of the disposition system are emphasised by and within research, for instance, whether individual position and career-specific facets or social group and class-specific issues are the primary focus of attention (Schwingel 2000,71). Habitus functions as a sense of orientation by ensuring that, on the basis of the inherent social sense, adequate practices are generated in the social world in general and in certain social fields in particular. Social actors themselves are not aware of their habitus dispositions as they have no conscious memory of its social genesis and history. However, despite the social conditionality of the habitus, it only sets the boundaries of perceiving, thinking and acting rather than determining the social practices themselves. Within this conditioned and conditional freedom, as Bourdieu $(1987,103)$ stresses, scope for variation, even for innovation, exists. From the point of view of habitus, social actors' individuality consists of making use of this field- or group-specific scope.

To understand the concept of habitus, it is crucial to consider the dialectical relationship of "habitus" and "field", particularly when it comes to understanding the role of habitus in social continuity or change. Both continuity and transformation are theoretically possible and plausible depending on the relation of the conditions of a habitus' origin and the circumstances of its actualisation. In the case of correspondence between the two, the habitus - as "structured structures predisposed to function as structuring structures" (Bourdieu 1990, 53) - induces a circular process leading to a stabilisation and reproduction of social structures. In contrast, transformative processes are more likely to occur in the event of a discrepancy between the conditions of origin and circumstances of actualisation, external change or engagement in unfamiliar social fields. Moreover, it should not be forgotten that habitus dispositions, as incorporated experiences and processes of socialisation, are subject to continuous change as well. However, according to Bourdieu (1990, 62), an individual's early conditioning remains relatively stable and has a lasting impact, which he calls "inertial effect" or "hysteresis effect". Therefore, we must theoretically expect a delayed adaptation of habitus to objective structures and the transformation of patterns of perception, thought and action to evolve slowly and gradually.

What is often forgotten or unknown is that Bourdieu developed his theoretical approach through empirical research and considered the habitus concept as a heuristic tool (Bourdieu 1990). Here it is applied as professional habitus (and) to the field of prostitution governance. In light of the question of how frontline governance actors deal with prostitution and make sense of it against the backdrop of existing legal and organisational frameworks, the concept of professional habitus represents a promising theory-sensitising tool as it aims to explain the genesis of social practices and representations, and more specifically, includes moral intuitions. The "moral imaginary", in J antzen's $(2010,173)$, can be thought of as one aspect of the habitus. For this purpose, let us draw on Bourdieu $(1998,8)$ himself:

Habitus are generative principles of distinct and distinctive practices (...). But habitus are also classificatory schemes, principles of classification, principles of vision and division, different tastes. They make distinction between what is good and what is bad, between what is right and what is wrong, between what is distinguished and what is vulgar, and so forth (...). But the essential point is that, when perceived through these social categories of perception, these principles (...) become symbolic differences and constitute a veritable language. (Bourdieu 1998, 8; my italics)

However, the relation between social structure and agency, between law in books and law in action, and between policy framework and governance actors' professional habitus remains an open question that can only be answered empirically in regard to 
a certain field and the "nature" of the situation. To do so, we will first turn to methodological aspects and then to the results of this qualitative empirical study.

\section{Methodology: Making use of expert interviews to explore the law in practice}

The findings presented in this article were obtained through a research project on the governance of prostitution in Germany (in the state of Saxony in particular), the Czech Republic and Poland. The study was conducted at the Department of Political Science at the University of Leipzig (2004-2006) and, with a focus on Germany only, followed up at the Department of Sociology at the University of Magdeburg (20062008). ${ }^{3}$ This study aimed to examine governance from below in terms of the everyday practices and structures of meaning of governmental and civil-society frontline actors. Starting from the basic methodological assumption of qualitative social research that the social construction of reality, and the production of meaning in particular, is essentially reflected in language and terminology, the study drew on qualitative interviews, or more precisely, the method of "theory-generating expert interviews" (Bogner and Menz 2009) developed by Meuser and Nagel $(1991,1994)$.

Expert interviews represent a special type of qualitative interview, focusing, as the name implies, on specialist or expert knowledge that stems from participation in certain institutions, professions or social movements (Meuser and Nagel 1994). Following Froschauer and Lueger (2009), we can differentiate three types of expertise: hands-on expertise internal to the field, reflexive expertise internal to the field, and external expertise. Frontline actors generally possess internal expertise that is experience-based and practice-oriented. It derives from first-order observations (Schutz 1962) and is tacit knowledge embedded in schemes of perception, thought and action. The experiential knowledge of actors in the field appears extremely heterogeneous, as Froschauer and Lueger (2009) argue, because, at the subject level, the sedimentation of experience is guided by the individual's lifeworld background and structures of relevance. In addition to commanding specialist knowledge, experts are generally defined by having power of definition, decision-making authority and, in some cases, control over implementation due to their social position and status in certain social arenas (Meuser and Nagel 1991, 443).

The research project conducted 35 interviews with governmental and nongovernmental frontline actors in the social arena of the governance of prostitution and human trafficking for the purpose of sexual exploitation in Germany, Poland and Czech Republic. The findings presented here are from in-depth analyses of the German interview conversations that were conducted from 2004 to 2007. The theoretical sampling applied in selecting the interviewees systematically reflects the fundamental functional differentiation of the governance field by including interview partners from different organisational and professional contexts such as the police force and regulatory authorities on one hand and social work and public-health providers on the other.

The theory-generating form of the expert interview goes beyond interviewing experts either to merely gain insight into a social phenomenon or to systematise existing expertise on a certain topic - prostitution, for instance - by drawing on experts' "context knowledge". What it aims to accomplish instead is to examine experts "operational knowledge" (Meuser and Nagel 1991, 1994, Bogner and Menz 2009). Moreover, it intends to both develop and scrutinise the theoretical concepts that were chosen to serve as a theory-sensitising tool. To study law in action in the field of prostitution, Bourdieu's (1990) concept of "habitus", as outlined in the previous section, functioned as such a heuristic concept. Applied as professional habitus, it was used to frame the main research questions: How do frontline actors in relevant

\footnotetext{
${ }^{3}$ The former was funded by the Higher Education and Science Programme of the German state of Saxony and the latter by a postgraduate scholarship from the German state of Saxony-Anhalt.
} 
public-administration and civil-society organisations perceive prostitution and how do they refer to it? What are the underlying patterns of classification? How do they govern prostitution in their everyday work and through their mundane governance practices?

In order to reconstruct public officials' professional habitus, all expert interviews were digitally recorded and most of them fully transcribed. The transcribed interview material was systematically analysed following the methodical procedure suggested by Meuser and Nagel (1991, 455 ff., 2009, 35 ff.). However, my research interest in professional habitus as well as striking differences in the patterns of perception, thought and action among the interviewees suggested adjusting the methodical procedure by incorporating the method of case analysis and case comparison. As a research result, the heuristic concept of professional habitus could be refined and, equally important, proved to be conducive to gaining a deeper understanding of governance processes, particularly of law in action at the level of implementation.

\section{Findings: Professional habitus and individualised governance practices}

The subsequent section presents the findings of the study examining governance of prostitution from a bottom-up perspective. It provides insight into how frontline actors make sense of their organisational and occupational tasks as well as how and to what extent the legal regime is put into practice at the local level. First, the empirically grounded and refined concept of professional habitus is outlined. A comparison of two contrasting cases in the field of public health follows to demonstrate the theoretical and practical significance of the habitus concept by systematically capturing and explaining differences in local governance practices.

\subsection{Theoretical model: Professional habitus formations concerning prostitution} governance

The in-depth interview analyses revealed that governmental and non-governmental actors' schemes of perception, thought and action encompass three key dimensions, which I have called the "definition of the issue", "definition of the self" and "definition of the environment" (see Table 2; see Vorheyer 2010, 197ff). This is merely a theoretical-analytical distinction; in practice the facets are invariably interlinked. The definition of the issue, as the first element, consists of social frames (Goffman 1974, 21), social categorisations and social problematisations concerning prostitution. It captures public officials' responses to the issue of prostitution, that is, how prostitution is perceived and interpreted, who or what is problematised, and in which ways the people involved, for instance, sex workers and their clients, are categorised. The second dimension of professional habitus, the definition of the self, comprises the professionals' primary approach to their work and the methods applied as well as their professional self-conception. It informs us which areas and objects concerning the issue of prostitution frontline actors focus on in their daily practice, which strategies and policies they employ, and finally on which professional self-concept their actions are based. The third element, the definition of the environment, involves relationships to other organisations within the governance arena as well as their underlying principles of collaboration or demarcation. The following case analysis and case comparison, however, focus on the first two dimensions. 
TABLE 2

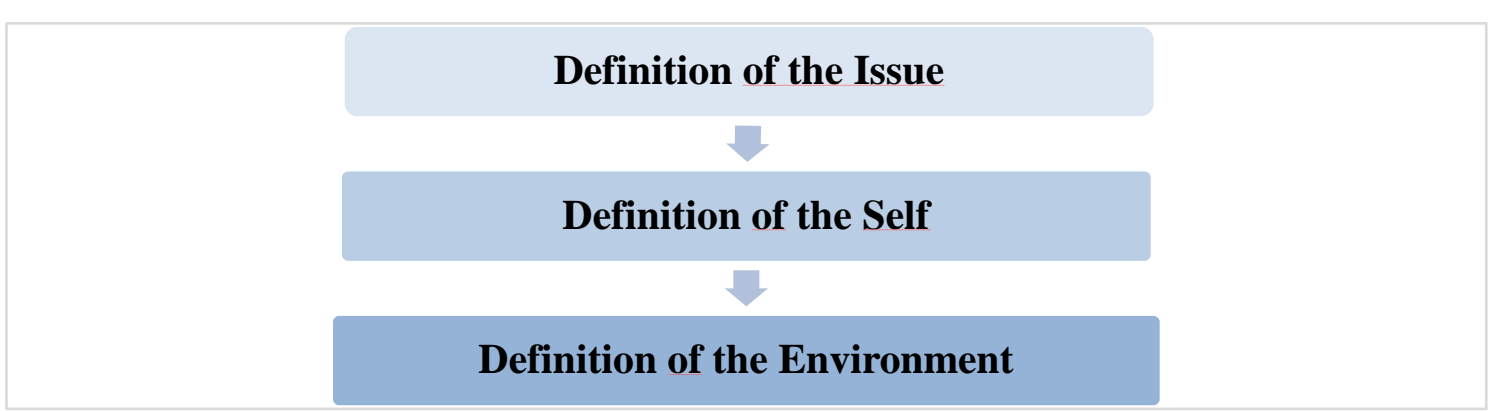

Table 2. Theoretical model of professional habitus formation.

Overall, the expert interviews with frontline actors governing prostitution revealed not only theoretically anticipated institutional and professional differences but also striking individual variations.

4.2. Case comparison: Divergence of "policy in use": Control-oriented vs. prevention-oriented public health approach

The following contrastive case comparison is based on two interviews with publichealth officials that were conducted during the third year after the legislative change in Germany from a regime involving mandatory medical examinations for so-defined risk groups towards a policy based on prevention and voluntary services (see introduction). However, as we will see, while one of these public-health officials realised and even anticipated the paradigm shift, which occurred in some other cities and regions as well (Steffan et al. 2002), the other public servant has not entirely committed to implementing it (yet) since the legal framework conflicts with her professional schemes of perception, thought and action.

Empirically, in regard to the practice of public-health authorities, the research found two divergent patterns of perception, thought and action among the frontline actors operating under the same legal framework and in charge of fulfilling the same task: namely, a public-health professional with a "monitoring- and control-oriented" approach on the one hand and another one with a "counselling- and preventionoriented" approach on the other (see Table 3). Those different professional habitus formations clearly shape public-health policy in different ways at the local level, as we will learn in greater detail below.

In regard to their definition of the issue - the first facet of the professional habitus concept-it becomes apparent that the control-oriented public-health professional perceives prostitution merely through a medical frame:

Our concern is that they (the sex worker-my addition) are healthy when they are working. That's it. There is no more to it than that. That's our job, actually.

Her prevention-oriented counterpart, by contrast, refers to prostitution not only from a health perspective but additionally from a social-work point of view:

It is not just about health issues. Sure, that is our main concern, right? However, the social issues (...), since I am the only contact person, all the other problems come up as well. Where else should they go? I can't just say to them: 'Stop, this is where my job ends'.

Consistent with her medical frame, the first public-health official criticises the abolition of the previous practice of mandatory health check-ups for sex workers and problematises the increasing diseases among her clients. Her client interactions appear fairly ambivalent, characterised by sympathy and tolerance on the one hand and latent stigmatisation and resentment on the other, as she pictures her relationship with them as personal, almost private, yet complains considerably about their unreliability and naivety. Moreover, in her everyday regulatory practice, she 
treats sex workers in an infantilising manner, as the following interview excerpt illustrates:

And then, when they [the sex workers - author's addition] are done here, they can reach into the big jar of condoms. Like candy. There are also colourful ones inside. They always like doing that. It's also another incentive [to come to us -author's addition]. Anyway (...). And when Christmastime comes around, we always have some small gifts for them. In that respect, they are like children. For the most part, they don't have anyone else. So, we make presents every year. And they are always asking if they will be getting something for Christmas again. Or if it's their birthday when they come here, they get something as well. That we do. They always come. They are like kids. They are always pleased then. So, we keep doing things like that.

In contrast to this, and opposed to the fact that the job is officially focused on publichealth, the prevention-oriented frontline actor, who works in another municipality, points to increasing social problems and cases in need of social counselling and support.

I also just had a client who didn't have any teeth anymore, or almost didn't. Now she's got dentures. She wears them. Great! She's happy. But she wouldn't have managed on her own. She wouldn't have gotten to the point of re-establishing her position in society that she had lost because of being toothless. Social stigmatisation. It's great now. She feels at ease. Therefore (...) these are things like that, right? In these situations, one has to (...). And it is also support to get by again, to manage life a bit better.

Nevertheless, she perceives her clients as self-reliant persons and considers them as risk-sensitive and responsible professional sex workers, as the following quotation indicates:

Many of them do indeed work professionally. Particularly since many hide their identity when they leave the house in the morning, until the evening. Nobody knows what she is doing. Well, what they say, it's a variety of occupations (...). For this reason, I do think that many of them are aware of their responsibility [for their families - author's addition] and therefore say: 'Here, this is my job. I do this professionally. I don't want to catch anything that would come back to haunt me.'

These divergent patterns regarding the definition of the issue are also reflected in their definition of the self, the second key dimension of the concept of professional habitus proposed here. In this regard, the control-oriented public-health professional acts primarily as a nurse, whereas her counterpart in the other city identifies herself with the role of a social worker equipped with certain medical knowledge. Accordingly, their approaches to their everyday work revolve around medical examination for signs of sexually transmitted diseases:

Because I don't really see myself as a social worker in that sense, because I deal more with what almost comes down to medical concerns. As I said, the consulting hours here. That you can judge. We can (...), we know when it is syphilis or so. This is all because one has learned it all from day one (...). So nobody can fool me in that regard.

And advising on safe sex work as well as on social matters:

Well, as I said before, they say: 'Where have you been for so long?' [Referring to their field visits - author's addition]. So they want be in touch. Even if it's just deepening their knowledge about condoms, giving some lubricant - we always give them a few condoms and some lubricant - that you (...). Then, they almost always have questions on their minds. Whether they concern unemployment benefits or some other problematic issues. That has increased there too but not so much that I need to arrange for someone to assist them or something, it's just talking with them at that point.

Furthermore, their professional activities take place at different locations: in accordance with her understanding of her job, the control-oriented professional pursues her work in the official setting of the public-health authority in the form of a "walk-in model", whereas her prevention-oriented counterpart goes about her work 
with a focus on street work. Accordingly, the principles guiding their work vary significantly between a regulatory and controlling attitude on the one hand:

And they get their so-called Bockschein [identification card -author's addition], in quotation marks. That is their ID. It's no longer compulsory, but we give all of them one anyway because then we can keep track of them. It has their names on it, Maria, or whatever, their date of birth, and it bears the stamp and signature of the doctor, so that we can see that they visited the local health department and everything is fine.

and a pedagogical disposition in which refreshing the prostitutes' preventive knowledge as well as reminding them to get their health check-ups are considered as being an essential and natural part of the job on the other:

(A)nd that [the on-site visits - author's addition] is at the same time a reminder for a refresher on prevention and also a reminder that they might get, that they could definitely use a check-up again.

With respect to the legal change, the previous excerpt from the interview with the control-oriented public-health official reveals that, in her work, the revised law remains a law in books. In contrast, the legal paradigm shift clearly resonates with the patterns of perception, thought and action of the prevention-oriented official, and she actively puts it into practice in her everyday work, as the following quotation demonstrates:

With the abolition of mandatory health check-ups, it is certainly clear that (...) that they don't have to come. And that is also always our opening statement, that our service is an anonymous and voluntary one, that there is no (...) um (...) obligation of any kind. And, and this immediately signals to the women: 'What I do, what I make use of, I do so of my own free will.'

\section{TABLE 3}

\begin{tabular}{|l|l|l|}
\hline Public-health officials & $\begin{array}{l}\text { Monitoring- and control- } \\
\text { oriented }\end{array}$ & $\begin{array}{l}\text { Counselling- and prevention- } \\
\text { oriented }\end{array}$ \\
\hline Social frame & Mefinition of the Issue \\
\hline Problem definition & $\begin{array}{l}\text { Abolition of } \\
\text { mandatory health check-ups. }\end{array}$ & $\begin{array}{l}\text { Prevention, social work. } \\
\text { (ncreased need for social counselling } \\
\text { (in terms of work capacity). }\end{array}$ \\
\hline Social categorisation & Infantilisation of prostitutes. & Professional sex worker. \\
\hline Working approach & $\begin{array}{l}\text { Monitoring of medical checkup. } \\
\text { "Walk-in model". }\end{array}$ & $\begin{array}{l}\text { Health prevention and social work. } \\
\text { "Outreach work". }\end{array}$ \\
\hline $\begin{array}{l}\text { Problem- solving } \\
\text { strategy }\end{array}$ & $\begin{array}{l}\text { Mandatory health control (STD). } \\
\text { Block-out of social problems. }\end{array}$ & $\begin{array}{l}\text { On a voluntary basis: refreshment } \\
\text { of prevention knowledge, reminder } \\
\text { of medical check-ups. } \\
\text { Social counselling and referral to } \\
\text { other service providers. }\end{array}$ \\
\hline
\end{tabular}

Table 3. Case comparison: Divergent professional habitus of public-health officials. 
Comparing these two divergent policies in practice toward prostitution and public health, which differ despite the same legal framework and comparable working situations, raises the pressing question of what the reasons for this discrepancy are. The career paths of the two public-health officials show similarities as both are trained nurses and "welfare workers" (in German: Fürsorgerin) who at a later time pursued additional training to become social workers. When asked about this, the "monitoring- and control-oriented" frontline actor mentioned enrolling in a furthereducation programme, whereas the "counselling- and prevention-oriented" publichealth official referred to the study of social work. As the data does not provide detailed information on the interviewees' whole professional career, we can only speculate whether or not, or to what extent, their different designations of their further professional education and training refer to qualitatively different types of programmes. What is obvious in the case of the control-oriented professional, however, is that her further training as a social worker did not have a strong impact in terms of altering her professional habitus. Her monitoring- and control-oriented schemes of perception, thought and action were formed by her primary professional socialisation as a nurse and "welfare worker" and consolidated by her long working life in public-welfare institutions in the special socio-political context of the GDR regime, which cannot be discussed in greater detail here.

What the analysis of the expert interviews demonstrates in summary is that the professional patterns of perception, thought and action among frontline actors in prostitution governance can vary not only institutionally and professionally but also individually to a significant degree. The presented case comparison of public-health professionals exemplifies that individual differences in professional habitus are likely to lead to varied implementation practices and forms of governance at the local level even under the same legal framework and comparable circumstances.

I will conclude in the following by discussing these findings of a refined concept of professional habitus formation and the newly developed concept of an "individualised governance practice" and relating them to the literature on public administration, particularly to "street-level bureaucracy" and the concept of "morality politics" (Wagenaar and Altink 2012).

\section{Discussion: Prostitution governance and street-level bureaucracy: Professional habitus in the context of morality politics}

On the basis of a case study in the domain of public health, this article explored how the law in books works in the everyday reality of prostitution governance. In so doing, it attempts to counterbalance the prominent focus on policies codified in law, which is widespread despite the large body of scholarly literature that generally argues for the need to look at policy implementation. Drawing on expert interviews, the present research revealed how and to what extent policy realisation at the local level differs not only within but also from the given legal framework. This is so because prostitution policy is evidently influenced by frontline actors' professional habitus, which is not only shaped by legal regulations but also by their professional orientation and common-sense knowledge. The reconstructed fundamental differences in their patterns of perception, thought and actions were captured by three empirically grounded dimensions - the "definition of the subject", "definition of the self" and "definition of the environment". These dimensions refine the concept of professional habitus, which served as a heuristic approach for examining prostitution governance from a bottom-up perspective. Both empirically and theoretically, the concept of professional habitus provides deeper insight and a more profound understanding of how legal regulation is translated into everyday policy practices. It makes sense of variations in the way that policies are implemented within the same national frameworks - as observed both here and elsewhere (for instance, Wagenaar and Altink 2012, Amesberger 2014) - by conceptually pointing to the origin of such variations in the schemes of perception, thought and action. Moreover, professional habitus, understood as a sensitising concept, carries the potential for integrating 
crucial influencing factors beyond the legal framework and institutional context, for instance, professional socialisation and the evolved professional ethos, social class as well as political or religious affiliations, social movements, and societal systems, moral intuition and common sense.

It is only surprising at first glance that the results of such "individualised governance practices" are in line with scholarly literature on "street-level bureaucracy" - as opposed to Weber's (1978) conceptualisation of public administration as characterised by bureaucracy in terms of an impersonal rule-based and therefore legitimate, rational-legal form of organisation serving democratic-constitutive principles of the political order -. Against the background of the pioneering work of Lipsky (1980), the fact that frontline officials' actions diverge from stated policy is neither uncommon nor do they do so only to a minimal extent. However, beyond this broad approach, researchers are challenged to detect empirical regularities and generalisations, for instance and particularly relevant here, by understanding under which conditions frontline actors are motivated and able to obey political orders and legal obligations, follow constitutive or professional codes of behaviour, or act in a self-interested manner or as spokespersons for specific causes or groups (Olsen 2005, 19).

Across the numerous studies on public administration that May and Winter (2007, 453) reviewed, they identified four sets of influences on street-level bureaucrats' actions in implementing policy: first, signals from political and administrative superiors about the content and importance of the policy; second, the organisational and managerial structures, for instance, the extent to which organisations delegate authority for decision-making to the frontlines or limit that discretion; third, knowledge and attitudes of street-level bureaucrats concerning relevant tasks, their work situation and clients; and forth, contextual factors such as workload, client mix and other external pressures. However, in their own quantitative empirical study on the municipal implementation of employment policy in Denmark, May and Winter $(2007,469$ f.) found that the impact of the specific policy as well as political and managerial influences are relatively weak. Instead, it became evident how policy practices of the caseworkers are shaped by their understanding of policy goals, professional knowledge and policy evaluation. As a result, they concluded (May and Winter 2007, 470), referring to Brehm and Gates (1997, 202), that substantial numbers of caseworkers seems to be "principled agents" in fulfilling their professional roles in the context of implementing national policy and reforms.

The findings on prostitution governance presented here confirm this - despite resting on a different theoretical approach, methodology and empirical foundation - as the initial question of and focus on how frontline governance actors make sense of prostitution and act thereupon turned out to be a key factor in explaining differences in policy implementation (Vorheyer 2006). Thus, the findings of the present study are not only in line with but also reinforce Wagenaar and Altink's (2012) request for putting more emphasis on the mundane details of policy implementation in the field of prostitution governance. Similar to May and Winter's (2007) research on employment policy, this qualitative study on prostitution governance was carried out after an official policy change. It can be concluded that the paradigm shift in prostitution governance in the area of public health was realised or even anticipated by some frontline actors and local authorities, whereas others have yet to adapt their approach. How the actors respond to this shift depends primarily on the degree of congruity between the legal approach and their incorporated professional habitus. In the case of the control-oriented professional, this means that her professional habitus shows - theoretically consistent - a strong continuity with the previous controloriented approach to public health, which "trumps" the change in policy. By contrast, the prevention-oriented professionals' schemes of perception, thought and action correspond with the ensuing prevention-based policy. Of course, no conclusive statements can be made about how many street- level bureaucrats observed the spirit of the revised law or not. However, one of the main contributions of this study 
consists of showing how the professional habitus provides a nuanced understanding of how policies codified into law are translated into action on the ground.

A particularly important reason to focus on the "law in action" in prostitution governance is what Wagenaar and Altink (2012) refer to as "morality politics". Morality politics is generally defined by six key characteristics: it is "driven by explicit ideology, almost exclusively owned by the general public, impervious to facts, discussed in emotionally highly charged language, concerned more with the symbolism of heroic measures than the details of implementation, and prone to sudden policy reversals" (Wagenaar and Altink 2012, 285). I would like to argue that all these characteristics are worth considering and promise a fruitful discussion in connection with the concept of professional habitus as this combination strengthens the relevance and explanatory power of both morality politics and professional habitus with regard to everyday policy practice. I will briefly demonstrate this exemplarily by connecting them with social actors' schemes of perception, thought and action.

Morality politics, according to Wagenaar and Altink $(2012,283)$, is ruled by ideology and shaped by more or less tacit ideas and understandings of basic social norms and values, thereby rendering such moral and cognitive orders self-evident and hegemonic and naturalising them so that they are hard to recognise as a (specific) position among possible others at all. The ideologies and the moral imaginary concerning prostitution and prostitution governance, respectively, are a constitutive part of the habitual patterns of thinking that largely remain implicit for policy makers as well as policy implementers up or down to the level of street-level bureaucrats. Theoretically speaking, the habitus is an operative category linked to knowledge, particularly to implicit knowledge, but goes far beyond it (Kastl 2007, 384). It consists of embodied dispositions in terms of tendencies that organise the ways in which we perceive and react to the social world around us. Therefore, by linking knowledge and normativity, law and morality, policy and habitus, it is neither surprising nor unexplainable how everyday governance practices of frontline actors function as a "vehicle for a larger moral cause" and often transport a "pedagogical thrust" (Wagenaar and Altink 2012, 283) - corresponding with or opposed to the legal framework - as the contrasting case comparison presented here has demonstrated.

Moreover, in the light of the defining criterion that morality politics is lay policy, meaning experts seem to have limited authority as everyone has a sense of "owning" prostitution policy (Wagenaar and Altink 2012), the impact of the street-level bureaucrats' patterns of perception, thought and action on the law in action including potential divergences from implicit or explicit policy ideas - appears even more plausible and explainable. While governance frontline actors are public officials and often professionals, they are lay persons at the same time. They "know" - at least from their point of view - what the "problems" and the "right" approaches to prostitution are. Thus, their experience-based expertise gained in the field can be considered as "hybrid knowledge", which, according to Valverde (2003), comprises not only "high-status knowledge", in terms of scientific, specialised and professional knowledge, but also "low-status knowledge", referring to common sense and perceptions about morals, decency and public order.

In conclusion, administration theory, as Olsen $(2005,18)$ states, has to acknowledge the complexity of administrative organisation, actors and change. Doing so requires that we take into account the significant role of frontline officials in putting law into practice. In this respect, the habitus concept provides insights into how organisational structures and legal regulations are translated into behaviour. In light of the current paradigm shift and the implementation of the actual Prostitution Protection Act in particular, the question of what changing the law changes remains, or rather becomes a very topical issue again. In order to answer this question empirically, it suggests itself to examine the current law in practice and compare the results with the findings in terms of the "individualised governance practices" presented here. 
Given that these results accord with the literature on public administration and streetlevel bureaucracy, it seems very likely that they can be generalised to the implementation of prostitution policy within other national, legal and administrative contexts. However, future research is needed to demonstrate and further underpin the relevance of the habitus concept and to refine the theoretical explanation of law in practice. Beyond purely academic issues, the law in action proves to be vital for the effective implementation of the policy objectives and procedures on the one hand and, more generally, for the legitimate functioning of the law-based bodies of public administration on the other.

\section{References}

Amesberger, H., 2014. Sexarbeit in Österreich. Ein Politikfeld zwischen Pragmatismus, Moralisierung und Resistenz. Vienna: New Academic Press.

Bogner, A., and Menz, W., 2009. The theory-generating expert interview: Epistemological interest, forms of knowledge, interaction. In: A. Bogner, B. Littig and W. Menz, eds., Interviewing Experts. Basingstoke: Palgrave Macmillan, 43-80.

Bourdieu, P., 1987. Sozialer Sinn. Kritik der theoretischen Vernunft. Trans.: G. Seib. Frankfurt am Main: Suhrkamp.

Bourdieu, P., 1990. The Logic of Practice. Trans.: R. Nice. Cambridge: Polity.

Bourdieu, P., 1998. Practical Reason: On the Theory of Action. Redwood City, CA: Stanford University Press.

Brehm, J., and Gates, S., 1997. Working, Shirking, and Sabotage. Bureaucratic Response to a Democratic Public. Ann Arbor: University of Michigan Press.

Di Nicola, A., et al., 2005. Study on National Legislation on Prostitution and Trafficking in Woman and Children. Milan: Transcrime. Joint Research Center on Transnational Crime, European Parliament.

Frommel, M., 2015. Prostitution: Beyond an Infantilising Feminism. Research Project Germany [online], 4 January. Available from https://researchprojectgermany.wordpress.com/2015/01/04/prostitutionbeyond-an-infantilising-feminism/ [Accessed 12 November 2018].

Froschauer, U., and Lueger, M., 2009. Expert Interviews in Interpretive Organisational Research. In: A. Bogner, B. Littig and W. Menz, eds., Interviewing Experts. Basingstoke: Palgrave Macmillan, 217-234.

Galen, M. von, 2004. Rechtsfragen der Prostitution. Das ProstG und seine Auswirkungen. Munich: C.H. Beck.

Goffman, E., 1974. Frame Analysis. An Essay on the Organization of Experience. Cambridge, MA: Harvard University Press.

Jackson, G., 2009. Actors and Institutions. University of Bath, School of Management, Working Paper Series [online], July. University of Bath, School of Management. Available from: http://www. bath.ac.uk/management/research/pdf/2009-07.pdf [Accessed 12 November 2018].

Jantzen, G., 2010. A Place of Springs. Eds.: O. Carretti and M., J oy. London: Routledge.

Kastl, J.M., 2007. Habitus. In: R. Schützeichel, ed., Handbuch Wissenssoziologie und Wissensforschung. Constance: UVK.

Lipsky, M., 1980. Street-Level Bureaucrats. The Dilemmas of the Individual in Public Services. New York: Russell Sage Foundation. 
Mattson, G., 2016. The Cultural Politics of European Prostitution Reform: Governing Loose Women. New York: Palgrave Macmillan.

May, P.J., and Winter, S.C., 2007. Politicians, managers, and street-level bureaucrats: Influences on policy implementation. J ournal of Public Administration Research and Theory [online], 19 (3), 453-476. Available from: https://oied.ncsu.edu/selc/wp-content/uploads/2013/03/PoliticiansManagers-and-Street-Level-Bureaucrats-Influences-on-PolicyImplementation.pdf [Accessed 12 November 2018].

Mayntz, R., 1997. Soziologie der öffentlichen Verwaltung. $4^{\text {th }}$ revised ed. Heidelberg: UTB.

Mayntz, R., and Scharpf, F.W., 1995. Der Ansatz des akteurzentrierten Institutionalismus. In: R. Mayntz and F.W. Scharpf, eds., Gesellschaftliche Selbstregelung und politische Steuerung. Frankfurt am Main: Campus, 39-72.

Meuser, M., and Nagel, U., 1991. ExpertInneninterviews - vielfach erprobt, wenig bedacht: Ein Beitrag zur qualitativen Methodendiskussion. In: D. Garz and K. Kraimer, eds., Qualitativ-empirische Sozialforschung. Konzepte, Methoden, Analysen. Opladen: Westdeutscher, 441-471.

Meuser, M., and Nagel, U., 1994. Expertenwissen und Experteninterview. In: D. Hitzler, A. Honer and C. Maeder, eds., Expertenwissen. Die institutionalisierte Kompetenz zur Konstruktion von Wirklichkeit. Opladen: Westdeutscher, 180192.

Meuser, M., and Nagel, U., 2009. The expert interview and changes in knowledge production. In: A. Bogner, B. Littig and W. Menz, eds., Interviewing Experts. Basingstoke: Palgrave Macmillan, 17-42.

Olsen, J.P., 2005. Maybe it is time to rediscover bureaucracy. Public Administration Research and Theory [online], 16 (1), 1-24. Available from: https://doi.org/10.1093/jopart/mui027 [Accessed 12 November 2018].

Östergren, P., 2017. From zero tolerance to full integration. Rethinking prostitution policies. DemandAT [online], Working Paper No. 10. Available from https://www. demandat.eu/publications/zero-tolerance-full-integrationrethinking-prostitution-policies [Accessed 12 November 2018].

Schutz, A., 1962. The Problem of Social Reality: Collected Papers I. The Hague: Martinus Nijhoff.

Schwingel, M., 2000. Pierre Bourdieu. Zur Einführung. Hamburg: Junius.

Steffan, E., Rademacher, M., and Kraus, M., 2002. Gesundheitsämter im Wandel. Die Arbeit der Beratungsstellen für SODs und AIDS vor dem Hintergrund des neuen Infektionsschutzgesetzes (IfSG). Berlin: SPI-Forschung.

Valverde, M., 2003. Law's Dream of a Common Knowledge. Princeton University Press.

Vorheyer, C., 2006. Zur Bedeutung individueller Wahrnehmungs- und Handlungsmuster in der Rechtsanwendung. Das Beispiel der Verwaltung von Prostitution. Zeitschrift für Rechtssoziologie, 27 (2), 275-288.

Vorheyer, C., 2010. Prostitution und Menschenhandel als Verwaltungsproblem. Eine qualitative Untersuchung über den beruflichen Habitus [online]. Bielefeld: Gender Studies, transcript. Available from: https://www.transcriptverlag.de/978-3-8376-1412-1/prostitution-und-menschenhandel-alsverwaltungsproblem/ [Accessed 12 November 2018].

Wagenaar, H., and Altink, S., 2012. Prostitution as morality politics or why it is exceedingly difficult to design and sustain effective prostitution policy. 
Sexuality Research and Social Policy [online], 9 (3), 279-292. Available from: https://doi.org/10.1007/s13178-012-0095-0 [Accessed 12 November 2018].

Weber, M., 1978. Economy and Society: An Outline of Interpretive Sociology.

Oakland: University of California Press

Legal sources

Gesetz zum Schutz von in der Prostitution tätigen Personen [Prostitutes Protection Act], 2017. Available from https://www.gesetze-im-

internet. de/prostschg/BJ NR237210016.html [Accessed 26 July 2017].

Gesetz zur Regelung der Rechtsverhältnisse der Prostituierten [Prostitutionsgesetz, ProstG, Prostitution Act], 2002 [online]. Available from: https://www.gesetzeim-internet. de/prostg/B] NR398310001.html [Accessed 26 July 2017].

Gesetz zur Verhütung und Bekämpfung von Infektionskrankheiten beim Menschen [Protection against Infection Act], 2001 [online]. Available from:

https://www.gesetze-im-internet. de/ifsg/index.html [Accessed 26 July 2017]. 